\title{
The Effectiveness of Discussion Techniques on First Grade Students' Speaking Skills Junior High School
}

\author{
Nur Wahyuni ${ }^{1}$, Mulya Yusnarti ${ }^{2}$ \\ ${ }^{1}$ Dosen Program studi Pendidikan Bahasa Inggris, STKIP Yapis Dompu \\ 2Dosen Program Studi Pendidikan Guru Sekolah Dasar, STKIP Yapis Dompu \\ E-mail: n.wahyuni63@gmail.com, mulyayusnarti@gmail.com \\ Article History: Received: 2020-09-14 || Revised: 2020-10-02 || Published: 2020-10-26 \\ Sejarah Artikel : Diterima: 2020-09-14 || Direvisi: 2020-10-02 || Dipublikasi: 2020-10-26
}

\begin{abstract}
This Research Aimed To Find Out The Effectiveness Of Discussion Technugue Toward Students' Speaking Skill At The First Grade Students Of MT.S Darul Falah Duman In Academic Year 2018/2019. The Method Of This Research Was Applied Is Experimental Research (Quantitative Method). The Population Of This Research Was The Students Of MT.S Darul Falah Duman In Academic Year 2018/2019. The Sample Of The Study Was 36 Students Consist Of Two Classes. The Sample Technique Used In This Study Was Lottery Technique Sampling. The Technique Which Was Used To Analysis The Data Was Test Formula. From The Research Data Found Out That The Students' T-Test Score Is (7.606) And T-Table (2.042) From (Df) 36. Based On The Result Of The Study, It Can Be Concluded That The Use Of Grammar Translation Method Has Positive Effect Towards Students' Speaking Skill At The First Grade Students Of MT.S Darul Falah Duman In Academic Year $2018 / 2019$.
\end{abstract}

Keywords: Effectiveness Discussion Technique, Speaking Skill

\begin{abstract}
Abstrak
Penelitian ini bertujuan untuk mengetahui efektivitas teknik diskusi terhadap keterampilan berbicara siswa pada siswa kelas I MT.s Darul Falah Duman tahun ajaran 2018/2019. Metode penelitian yang diterapkan adalah penelitian eksperimental (metode kuantitatif). Objek penelitian ini adalah siswa MT.s Darul Falah Duman tahun ajaran 2018/2019. Sampel penelitian adalah 36 siswa yang terdiri dari dua kelas. Teknik sampel yang digunakan dalam penelitian ini adalah teknik pengambilan sampel melalui cara lotere. Teknik yang digunakan untuk analisis data adalah rumus tes. Dari data penelitian didapatkan nilai t-test siswa (7.606) dan t-tabel (2.042) dari (df) 36. Berdasarkan hasil penelitian dapat disimpulkan bahwa penggunaan metode grammar translation berpengaruh positif terhadap keterampilan berbicara siswa kelas satu MT.s Darul Falah Duman tahun ajaran 2018/2019.
\end{abstract}

Kata kunci: Efektivitas Teknik Diskusi, Keterampilan Berbicara

\section{PENDAHULUAN}

In globalization era which is symbolized by actual competition in various aspects need to master English as a means of communications. The best instrument for international communication is English. English is very necessary in science and technology. According to (Rabiah, 2018) English is a media of communication that human beings use to communicate each other in this world. English can make human beings have no difficulties when visiting other countries in this planet earth since English is an international language. In teaching English in Junior High School, the teacher perform many kinds of strategy in teaching learning activity because it has an important role in the teaching leaning process, therefore, the teacher should choose or find some strategies to be presented in the teaching learning activity. Mainly in the teaching speaking, as we know that the Junior High School finds some difficulties when the short ones, the teacher should create new strategy in the teaching process of foreign language. 
A creative and smart English teacher efforts to represent the material by varying her/his teaching skill. According to (Juni Bayu Saputra, 1387), it can be delivered in many ways. Namely, Direct method, grammar translation method or other technique, such us Drilling, gamming and role playing techniques, but in this case the researcher is going to use discussion as a strategy for the English teacher represent her/his material in lass. According to (Nurul Fajriah, Sofyan Abdul Gani, n.d.) Furthermore the strategy to be applied in learning process must be adapted with the instructional. The researcher believes that to teach speaking the teacher should choose selectively and apply appropriate strategy. Which is suitable for the needs of the students and for the condition of the environment.

In this study, the researcher uses discussion technique toward students" speaking ability, where, the discussion in small groups is a regular process which involves several groups of students in the informal interaction with various experience or information, making conclusion, or answering the problem. According to (Febrina Hanung Siswanti, Ngadiso, 2012) the meaning of discussion in small groups in the process of teaching learning is on different so far from the definition above. The students engage in the discussion of small group under the control of teacher or their friends for all sorts of information, making conclusion on answering the problem. The discussion goes on in the teaching learning process. Where, each student delivers their ideas freely and each student should obey the rules which have decided (Agus rahmat, S.Pd., 2017)

The researcher takes this title because the teachers at Junior High School seldom use discussion as their teaching technique in a teaching and learning process. The majority of teacher only use communicative or demonstration method in the class. Where the students are seldom given stimulus or opportunity to find out or study in the process of understanding material which is given by their teacher, (Arise, 2018). Whereas, in the Competence Base Curriculum (CBC), the students are trained and demanded to be active in the process of teaching learning. Where the students should be trained to be brave in deliver their ideas or opinion in a discussion. So that the students will feel secured, confident or relaxed when they are going to speak in front of their friends in the classroom.

\section{METODE PENELITIAN}

The researcher use an experimental method in this research where according to (Miller, 2005) that in formal terms an experiment is a means of collecting evidence to show the effect of one variable upon another. Experimental design comes in two forms: the true experiment and the quasi experiment. Thus, the writer choose the quasi experiment that it is an attempt to simulate the true experiment and is thus referred to by many researchers as a compromise design (Gerbing, 1984) The design of this research ispost test only control group design. This design controls for any confounding effects of a pretest and is an popular experimental design, the participants are randomly assigned to groups a treatment groups are measured on the post test.

$\begin{array}{llll}\text { Group A } & \mathrm{R} & \mathrm{X} & \mathrm{O} \\ \text { Group B } & \mathrm{R} & & \mathrm{O}\end{array}$

Stanley \& Campbell (1963)

To get the result of this reasearh, the quantitave approach is applied by the writer. A quantitative approach is one in which the investigatory primarily uses postpositive claims for developing knowledge (i.e., cause and effect thinking, reduction to specific variables and hypotheses and questions, use of measurement and observation, and the test of the ories), employs strategies 
of inquiry such as experiments and surveys, and collect data on predetermined instruments that yield statistics (Creswell, 1997) In collecting the data needed, the writer observe English classes at the school, particularly at the first year students of MT.s Darul Falah Duman in academic year $2018 / 2019$ about the effect of using small group discussion in teaching speaking.

\section{FINDING AND DISCUSSION}

\section{A. Finding}

This particular chapter deals with the interpretation and analysis of the data obtained since the investigation conducted. As the researcher stated on the first previous chapter, the interpretation will be quantitative data form, meanwhile, these quantitative results will be analyzed through well structured basic statistical computation, it means the figures of the data presented will be analyzed respectively untill the researcher finds out the last results of computation. In finding the data needed the researcher designed a research into two groups of subject that was given treatment. Back to the chapter III that according to Steve Miller"s theory, the researcher used population and sample. In this case, the researcher took two classes, they were VII A as experiment and VII B as control.

The scoring achievement procedure in the research, The students came forward in front of the class one by one and face to face with the researcher having an interview about small discussion technique. The data of this research were collected through post test which was given after the students of two groups had been treated with different treatments in which the test was consist of speaking test. To get the valuable data of the research, the researcher taught speaking by using small discussion technique for experimental group and for control group, researcher taught speaking by pictures. The researcher continued to calculate the scores of post-test of the experimental group and control group. The sample could be seen in the following tables:

Table 1. Score of post-test of experimental group

\begin{tabular}{|c|c|c|c|c|c|c|c|}
\hline \multirow[t]{2}{*}{ Object } & \multicolumn{5}{|c|}{ Criteria } & \multicolumn{2}{|c|}{ Scores } \\
\hline & Grm & Pro & Flu & Comp & Vocb & $X^{1}$ & $X^{2}$ \\
\hline DR & 1 & 2 & 1 & 1 & 2 & 7 & 49 \\
\hline FF & 2 & 2 & 2 & 1 & 3 & 10 & 100 \\
\hline GAF & 2 & 3 & 1 & 3 & 3 & 12 & 144 \\
\hline GA & 2 & 2 & 2 & 3 & 4 & 13 & 169 \\
\hline IM & 2 & 2 & 2 & 3 & 3 & 12 & 144 \\
\hline $\mathrm{KR}$ & 2 & 3 & 3 & 2 & 4 & 13 & 169 \\
\hline LDA & 2 & 2 & 3 & 3 & 3 & 14 & 196 \\
\hline $\mathrm{MHH}$ & 2 & 2 & 3 & 2 & 2 & 11 & 121 \\
\hline MRZ & 2 & 2 & 2 & 1 & 3 & 10 & 100 \\
\hline $\mathrm{MA}$ & 2 & 3 & 1 & 2 & 3 & 11 & 121 \\
\hline MI & 3 & 3 & 3 & 3 & 4 & 16 & 256 \\
\hline$M$ & 3 & 2 & 3 & 2 & 4 & 14 & 196 \\
\hline MA & 2 & 3 & 3 & 4 & 3 & 15 & 255 \\
\hline MF & 2 & 3 & 3 & 3 & 4 & 15 & 255 \\
\hline MR & 3 & 3 & 3 & 4 & 2 & 15 & 255 \\
\hline MSB & 3 & 3 & 3 & 4 & 4 & 17 & 289 \\
\hline NA & 2 & 3 & 3 & 3 & 1 & 12 & 144 \\
\hline RN & 2 & 2 & 2 & 4 & 4 & 14 & 196 \\
\hline TOTAL & 39 & 45 & 43 & 48 & 56 & 231 & 3069 \\
\hline
\end{tabular}


Table 2. Score of post-test of control group

\begin{tabular}{|c|c|c|c|c|c|c|c|}
\hline \multirow[t]{2}{*}{ Object } & \multicolumn{5}{|c|}{ Criteria } & \multicolumn{2}{|c|}{ Scores } \\
\hline & Grm & Pro & Flu & Comp & Vocb & $X^{1}$ & $X^{2}$ \\
\hline AA & 1 & 1 & 1 & 1 & 2 & 6 & 36 \\
\hline AR & 2 & 2 & 1 & 1 & 2 & 8 & 64 \\
\hline $\mathrm{AA}$ & 2 & 2 & 2 & 1 & 2 & 9 & 81 \\
\hline $\mathrm{AM}$ & 2 & 2 & 1 & 1 & 2 & 8 & 64 \\
\hline AN & 3 & 2 & 2 & 2 & 3 & 12 & 144 \\
\hline $\mathrm{AF}$ & 3 & 2 & 2 & 1 & 2 & 10 & 100 \\
\hline BNF & 1 & 1 & 1 & 1 & 4 & 8 & 64 \\
\hline $\mathrm{BR}$ & 3 & 3 & 2 & 2 & 3 & 13 & 169 \\
\hline EN & 2 & 2 & 1 & 1 & 2 & 8 & 64 \\
\hline FF & 3 & 3 & 2 & 2 & 3 & 13 & 169 \\
\hline $\mathrm{HA}$ & 2 & 2 & 2 & 2 & 3 & 11 & 121 \\
\hline LA & 2 & 2 & 2 & 2 & 4 & 12 & 144 \\
\hline MAE & 1 & 1 & 1 & 1 & 1 & 5 & 25 \\
\hline $\mathrm{MM}$ & 1 & 1 & 1 & 1 & 3 & 7 & 47 \\
\hline NA & 1 & 1 & 1 & 1 & 1 & 5 & 25 \\
\hline $\mathrm{PZ}$ & 2 & 2 & 2 & 2 & 2 & 10 & 100 \\
\hline PATC & 1 & 1 & 1 & 1 & 4 & 8 & 64 \\
\hline RF & 2 & 2 & 2 & 2 & 2 & 10 & 100 \\
\hline Total & 34 & 32 & 27 & 25 & 45 & 163 & 1583 \\
\hline
\end{tabular}

\section{B. Data analysis}

The discussion in this part of study deals with the analysis scores of the test. Researcher continued to calculate the mean scores, standard deviation scores and t-test of experimental group and control group. And analysis of scores could be formulated as follows.

1. Finding the mean scores of experiment and control groups.

a. Mean score of experiment

$$
\begin{aligned}
\bar{X}_{1} & =\frac{\Sigma X}{N} \\
& =\frac{231}{18} \\
& =12.83
\end{aligned}
$$

b. Mean score of control

$$
\begin{aligned}
\bar{X}_{2}= & \frac{\Sigma X}{N} \\
& =\frac{163}{18} \\
& =9.06
\end{aligned}
$$

2. Calculating the standard deviation scores of the experiment and control groups by using the following formula :

Standard deviation of experiment 


$$
\begin{aligned}
& S^{2}=\frac{\Sigma X^{2}}{N}-X^{2} \\
= & \frac{3069}{18}-12.83^{2} \\
= & 170.50-164.61 \\
= & 5.89 \\
S^{2}= & \sqrt{5.89} \\
= & 2.43 \\
S^{2}= & \sum X^{2}-X^{2} \\
N \quad & \\
= & 1583-9.66^{2} \\
= & 18 \\
= & 5.86 \\
S^{2}= & \sqrt{5.86} \\
= & 2.42
\end{aligned}
$$

3. Finding the standard deviation scores of the two groups, the researcher continued to find out the $t$-test.

$$
\begin{gathered}
t_{n 1+n 2}=\frac{\left(X_{1}-X_{2}\right) \sqrt{\left(N_{1}+N_{2}-2\right) N_{1} N_{2}}}{\left.\sqrt{\left(N_{1} S_{1}^{2}\right.}+N_{2} S_{2}^{2}\right)\left(N_{1}+N_{2}\right)} \\
=\frac{(12,83-9.06) \sqrt{(18+18-2) 18 \times 18}}{\sqrt{(18 \times 2.43+18 \times 2.42)(18+18)}} \\
=\frac{3.77 \sqrt{34 \times 324}}{\sqrt{(43.74+43.56)(36)}} \\
=\frac{3.77 \sqrt{11016}}{\sqrt{87.30(36)}} \\
=\frac{395.69}{56.06} \\
=7.060
\end{gathered}
$$

\section{Discussion}

In connection to the condition, the researcher concluded that analysis shown the used of technique discussion is effective in teaching speaking ability to the students. The alternative hypothesis $(\mathrm{Ha})$ which read the effectiveness of using technique discussion toward speaking ability to the students it from comparison above, it is clear that t-test is higher than t-table. 
Indicates that the degree of differences of the mean score is signification in both confidence level 0,05 (95\%). Therefore, it can be concluded that technique discussion toward speaking ability is accepted, while the null hypothesis (Ho) which read the effectiveness of technique discussion using toward speaking ability is rejected. From the result of investigation explained in the data analyzing and discussion above, it can be concluded that the data analysis shown the significance of technique discussion toward speaking ability is effective at the students of MTs Darul Falah Duman, so the alternative hypothesis (Ha) is absolutely accepted and the null hypothesis (Ho) is certainty rejected

\section{CONCLUSION AND SUGGESTION}

\section{A. Conclusions}

After doing the analysis of the data, the researcher found that the mean score of experimental group was higher than the control group but it did not guarantee the significance result. The mean score of experimental group was 12.83 and the mean score of control group was 9.06 while the standard deviation of experimental group was 2.43 and the standard deviation of control group was 2.42. But the result above did not guarantee the significance, therefore the $t$-test was used to find out it. The value of $t$-test was 7.060 with $\mathrm{df}$ of 36 . It was measured from the $t$-table and the critical value was 2.042 at the level of significance 0.05 (95\%). Based on the data found above, the researcher compared between $t$-test and $t$-table values. The result showed that $t$-test was higher than $t$-table, it means that small discussion technique was effective in teaching speaking.

\section{B. Suggestions}

Based on the conclusion, the researcher would like to present some suggestions as follows:

a. To the teacher

1. The teacher should use the small group discussion as the media in learning process because it consists of conversation or dialog. small group discussion could be also to be one of relaxation media for the students. They can explore their capability and express what they want to say.

2. The English teacher need to give chance for students to explore that they need when the English learning process so, they are going to be accustomed to it so that the students can learn English more easily.

b. To the students

1. The students hoped not to be shy when they are going to speak.

2. Don't be afraid of doing mistake when you want to speak.

c. To the next researcher

The next researcher can use the small group discussion for teaching another skill of English.

\section{REFERENCE}

Agus rahmat, S.Pd., M. P. (2017). Small groub discussion strategy towards student's. 14(1), 55-64.

Arise, N. (2018). The Effectiveness of Small Group Discussion Method in The Teaching of Reading Comprehension. Thesis, 20400113002.

Campbell DT, Stanley JC (1963). Experimental and quasi-experimental designs for research. Chicago: Rand McNally \& Company.

Creswell. (1997). Five Quality Approaches to Inquiry. In Qualitative Inquiry And Research Design: Choosing Among Five Traditions (pp. 53-84). http://www.uk.sagepub.com/upmdata/13421_Chapter4.pdf 
Febrina Hanung Siswanti, Ngadiso, E. S. (2012). the use of small-group discussion. 03529, 157-159.

Gerbing, D. W. (1984). Campbell and Stanley for Undergraduates. In Contemporary Psychology: A Journal of Reviews (Vol. 29, Issue 4). https://doi.org/10.1037/022808

J قالات مجمو عه= Juni Bayu Saputra. (1387). Teaching strategies. http://www.ghbook.ir/index.php?name

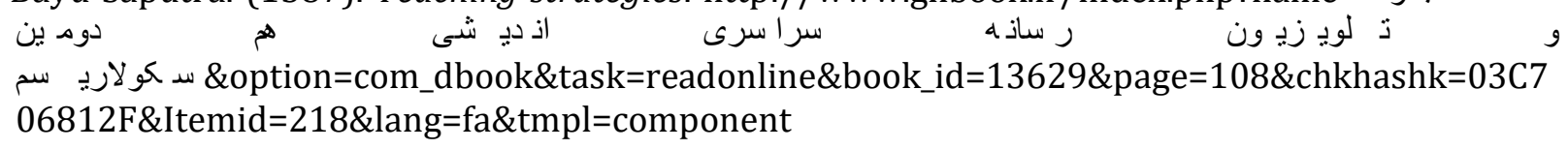

Miller, S. (2005). Experimental design and statistics. In Experimental Design and Statistics. https://doi.org/10.4324/9780203977644

Nurul Fajriah, Sofyan Abdul Gani, I. A. S. (n.d.). students' perseptions toward teacher's teaching strategies,. 2010, 16-34.

Rabiah, S. (2018). Language as a Tool for Communication and Cultural Reality Discloser. 1-11. https://doi.org/10.31227/osf.io/nw94m 